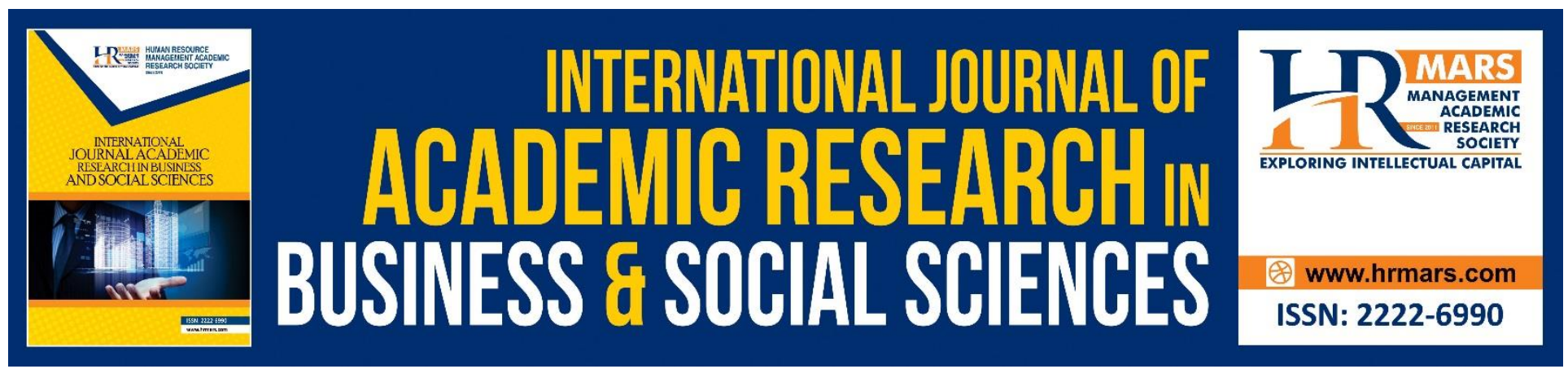

\title{
Al-'Aqĩdat Al-Șahihhat as the Essential Element of Worldview of Development Integrity and Accountability
}

Wan Khairul Aiman Wan Mokhtar, Wan Mohd Khairul Firdaus Wan Khairuldin, Abdullah Ibrahim, Abdul Hanis Embong

To Link this Article: http://dx.doi.org/10.6007/IJARBSS/v8-i11/4905 DOI: $10.6007 /$ IJARBSS/v8-i11/4905

Received: 30 Oct 2018, Revised: 19 Nov 2018, Accepted: 26 Nov 2018

Published Online: 27 Nov 2018

In-Text Citation: (Mokhtar, Khairuldin, Ibrahim, \& Embong, 2018)

To Cite this Article: Mokhtar, W. K. A. W., Khairuldin, W. M. K. F. W., Ibrahim, A., \& Embong, A. H. (2018). Al'Aqīdaț Al-Șahịnaț as the Essential Element of Worldview of Development Integrity and Accountability. International Journal of Academic Research in Business and Social Sciences, 8(11), 328-337.

Copyright: (C) 2018 The Author(s)

Published by Human Resource Management Academic Research Society (www.hrmars.com)

This article is published under the Creative Commons Attribution (CC BY 4.0) license. Anyone may reproduce, distribute, translate and create derivative works of this article (for both commercial and non-commercial purposes), subject to full attribution to the original publication and authors. The full terms of this license may be seen

at: http://creativecommons.org/licences/by/4.0/legalcode

Vol. 8, No. 11, 2018, Pg. 328 - 337

http://hrmars.com/index.php/pages/detail/IJARBSS

JOURNAL HOMEPAGE

Full Terms \& Conditions of access and use can be found at http://hrmars.com/index.php/pages/detail/publication-ethics 


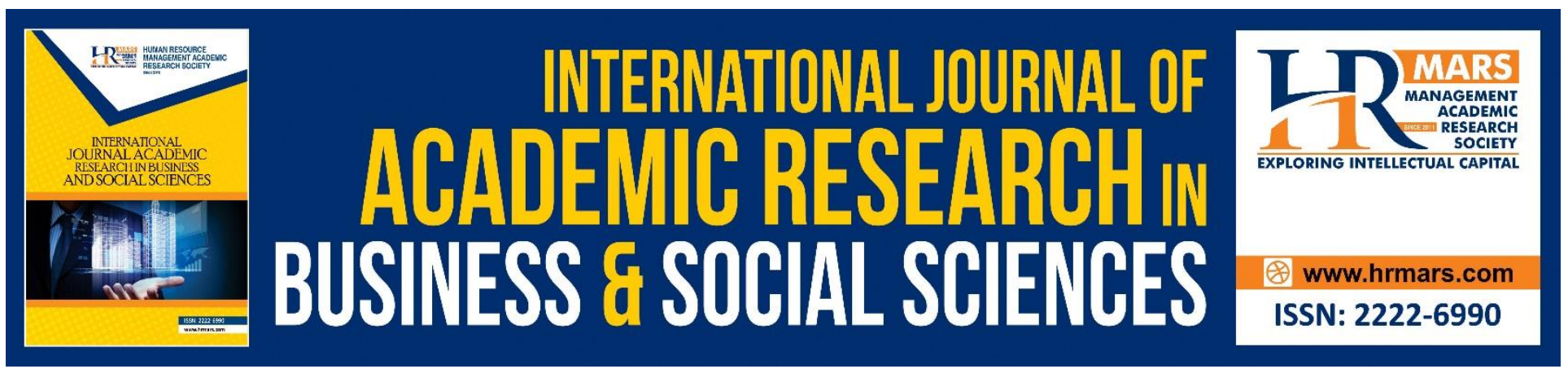

\title{
Al-'Aqĩdat Al-Șaḥiḥat as the Essential Element of Worldview of Development Integrity and Accountability
}

\author{
Wan Khairul Aiman Wan Mokhtar, Wan Mohd Khairul Firdaus Wan \\ Khairuldin, Abdullah Ibrahim \\ Universiti Sultan Zainal Abidin (UniSZA), Gong Badak Campus, 21300 Kuala Nerus, Terengganu, \\ Malaysia
}

\section{Abdul Hanis Embong}

Universiti Malaysia Terengganu (UMT), 21030 Kuala Nerus, Terengganu, Malaysia

\begin{abstract}
Commonly conventional development theories developed by conventional epistemology are the dominant development theories today. These or accommodated-modified theories are not appropriately applied to the development of Islamic countries as they are outside the Islamic paradigm. However, what is the concept of integrity and accountability development that can be applied? Hadith serves to fine-tune the Qur'an. Hence, what are the details of the hadith? Hence, it is necessary to study the worldview of development based on hadiths to achieve two objectives of the study. First, identify the hadiths related to the Islamic faith; secondly, analyzing the element of Islamic faith as an important element in development worldview. In order to achieve these two objectives, the study was in the form of exploration and descriptive by using the library method. Furthermore, the hadiths selected through the sampling method are to be analyzed using the content analysis method. As a result, this study concludes that it is an obligation to man to hold al-'aqidat alșahihhat element in all matters including in carrying out development activities. Based on this concept, humans can manage the development of better integrity and accountability in their lives.
\end{abstract}

Keywords: Islamic Faith; Worldview of Development Integrity and Accountability; Quran and Sunnah.

\section{INTRODUCTION}

The most important element in the concept of world view of development integrity and accountability based on the hadith is al-'aqidat al-ṣahịhat (true faith). This element is the cornerstone of all human practices in this world (al-Quḍāt, 2014). In the book named Șahịh al-Bukhāriy, there are 51 hadiths that explain this important element. However, researchers only choose four hadiths to 
INTERNATIONAL JOURNAL OF ACADEMIC RESEARCH IN BUSINESS AND SOCIAL SCIENCES

Vol. 8, No. 11, Nov, 2018, E-ISSN: 2222-6990 (C) 2018 HRMARS

analyze. This is because, the selection of the hadith is very much related to the elements of al-'aqidat al-șahihat which is discussed and further explains the objective of this study.

\section{RESEARCH METHODOLOGY}

This research is applying qualitative approach of exploratory and descriptive. The exploratory research is a formula of 'investigative focus' that is giving a clue towards the necessary identified results within a certain marvel. Meanwhile, descriptive research is purposely to describe "what", "when" or "how" of a particular phenomenon (Marican, 2005). The data were collected using a purposive sampling method. This research is using method of content analysis technique in examining the data. Hence, the data of this research are collected through library research methods and consequently been processed, organized and analyzed.

\section{FINDINGS AND RESEARCH DISCUSSION}

There are several hadiths that discuss this matter of faith. Rasulullah SAW said: From Abī Hurayrat r.a., the Prophet said:

"Allah SWT has created all beings. After the completion of the creation, the rahim (uterus) stands. So, God Almighty says, "Come closer to Me". Then said the womb, "This is the position that I take refuge from You from any termination". So Allah SWT says, "Do you lose if I connect anyone who connects you and I decide who decides you?". Answer the womb, "Yes, my Lord." Allah SWT says again, "So with that, I will accept your request" (History of al-Bukhari, Hadith No. 4830).

Hadith no. 4830 explains that only God Almighty created all beings and perfected them (al'Asqalāniy, 1379H: 580). Excerpts from Prophet Muhammad SAW khalaq Allāh al-khalq (Allah SWT has created all beings) showing all beings are created by Allah SWT. The creation includes humans and all physical and spiritual components are also events created by Allah SWT with His power (alSa'adiy, 2000: 752).

The opinion of al-Sa'adiy (2000: 752) is explained in more detail by al-Khalwatiy (t.th:38) which says Allah SWT creates all beings in the world. Between his power also, Allah SWT revives the physical and spiritual man in the hereafter. Such is the power of Allah SWT that cannot be matched by any inherent power. It shows the existence and power of Allah SWT is essential.

In addition, Hadith no. 4830 also explains when created by all creatures, appearing the rahim (uterus) to seek protection from Allah SWT. This proves that the main aspect mentioned in this hadith is the belief in proving that only Almighty Allah creates and empowers all things. Then, the rahim (uterus) expressed in this hadith is as a symbolic of human fulfillment of the instruction of Allah SWT and discharging his responsibilities as His being after adhering to the true faith (al-'Ayniy, t.th:240243).

Actually, there are also many verses of the Qur'an that explain the creation of this nature with the power of Allah SWT that is related to hadith no. 4830. Among them the word of Allah SWT:

Which means: Say, Allah SWT creates everything and He is the One Who is Powerful (al-

Ra'd, 13:16). 
INTERNATIONAL JOURNAL OF ACADEMIC RESEARCH IN BUSINESS AND SOCIAL SCIENCES

Vol. 8, No. 11, Nov, 2018, E-ISSN: 2222-6990 @ 2018 HRMARS

In addition, Allah SWT says:

Which means: And he created everything (al-An'am 6: 101).

The two examples of the Qur'anic verse reinforce the meaning of hadith 4830. All creatures that exist are created by Allah SWT without the need for anyone's help. That is why the scholars of al-Asyā'irat_ and al-Māturīdiyyat ${ }^{1}$ _ discuss the twenty obligatory qualities of Allah SWT. The obligatory nature of Allah SWT is not limited to the number twenty because the actual number is unknown to humans. However, it is obligatory for Muslims to know and adhere to these compulsory attributes (al-Fathani, 2009).

Referring to one of the twenty attributes of the scholar's discussion, the nature of al-Qudrat (Almighty) Allah SWT is unmatched. With this nature, Allah SWT created the heavens and the earth and all this nature. His possessions are absolute in order to make and eliminate something without any help. It also shows He is also characterized by one of the other qualities of the twenty compulsory attributes of Qiyāmuh bi Nafsih (do it Himself). This nature means that Allah SWT stands by itself and does not want the power, substance, place, etc. of the creatures (al-Bājūriy, 2010).

With the power and independence of Allah SWT to others, proves that He is the only God who is entitled to be worshiped and obeyed. However, this matter is totally rejected by the group called Atheists (non-religious). These people believe in the theory of evolution and bing bang. With this misleading theory, they judge that this nature exists naturally (al-Balīhiy, 1404H). Similarly, with some other religions such as Hinduism, Buddhism and so on who consider that this incident of nature does not belong to one god, they even assume that the universe was created and controlled by a great god. This group does not recognize the presence of Allah SWT who created, mastered and possessed this universe as a whole (al-Syahrastāniy, 1992).

In fact, Allah SWT has responded to the misguided views brought by these people in His words:

Which means: If there were in heaven and earth gods other than Allah SWT, both of them would have been destroyed (al-Anbiya ', 21:22).

Based on verse 22 of this surah al-Anbiyā', rationally Allah SWT has answered the inappropriate theory of non-Muslims. If there are so many gods in creating this universe, then it will surely be destroyed because the mind cannot accept the righteousness of God to be united and disputed in creating something. This argument is aqli (mental proof) evidence in responding to Allah SWT (al-Tanțāwiy, 1992: 2634). That is why the evidence of aqli and the evidence of naqli (excerpt proof) from the hadith no. 4830 shows that only Allah SWT alone has the power to create the universe and to control it. This is because, everything is categorized as Creator and created. The creator is named al-Khāliq and the created is called al-Makhlūq. Al-Khāliq is the One God who is Almighty Allah and apart from Him is classified as al-Makhlūq (al-Bājūriy, 2010).

Al-makhlūq or the universe is created by Allah SWT with two forms whether hissiyyat (sensory) or ma'nawiyyat (moral). Natural occurrences of the form of ma'nawiyyat can be traced to

\footnotetext{
${ }^{1}$ The al-Asyā'irat is a clergy scholars who adhere to the Abū Hasan al-Asy'ariy's Islamic beliefs, while the al-Māturīdiyyat golongan are the clerics who adhere to the Abū Manșūr al-Māturīdiy (al-Bājūriy, 2010) . According to al-Fathani (2009: 9), these two figures are the priests of Ahl al-Sunnat-wa al-Jamā'at.
} 
the prophecies that are conveyed to humans such as the creation of spirits, instincts, aristocracy, unseen, angels and so forth ('Ärîfiy, 1999). This includes the creation of the womb. It is clearly illustrated in the explanation of hadith 4830 which is the creation of Allah SWT like other creatures.

According to al-'Asqalāniy (1379H: 580), the rahim (uterus) comes from the word al-rahmat which means love. There are four possibilities that can be taken from the uterine state of speech. First, in fact the rahim (uterus) is actually saying the word; Secondly, the possibility of the rahim (uterus) turns into a human-like body and speaks; thirdly, the possibility that the words are an angel speaking to the rahim (uterus); and fourth, it is a gesture in the form of parables and passages. However, although there are some of the possibilities mentioned, it all shows the human responsibility to adhere to al-tawhid (the presence of Allah SWT) in his heart.

The same discussion about the creation of this al-makhlūq is also described in the hadith which reads:

Which means: Indeed Abā Hurayraț r.a. had heard the Messenger of Allah (peace be upon him) said: "Verily Allah has made a hundred parts of mercy, then He withholds 99 parts and drops one part to the earth. From this one part is the whole creature loving each other. Even until a horse raises his feet for fear of trampling on his son "(History al-Bukhāriy, Hadith No. 6000).

According to al-Suyūțiy, (1988), the 6000 hadith reconciliation is due to the arrival of a Bedouin Arabian with his camel ride. At the same time, the camel broke and the bastard Arabs tied it. Then, he prayed with the Messenger of Allah until the prayer was completed. Upon completion of the prayer, he went straight to the place where his camel was tied and let go of his bond. When he rides the camel, he prays:

"O Allah, bless me and Muhammad. Do not be blessed except we are also one ", then the Messenger of Allah said if you say this is heresy or her cam? Do not you hear what he says? The companions replied: "Right." The Messenger of Allah said: "He has narrowed a wide range of blessings. Indeed Allah SWT creates one hundred blessings, then Allah SWT sends down a mercy. With mercy those loving beings, their jinn and their human beings and their animals and Allah SWT end up on the side of 99 blessings, do you say he is lost or his cam? "(Al-Suyūțiy, 1988).

Al-'Asqalāniy $(1379 \mathrm{H})$ concludes that the two meanings derived from the ja'al words in the 6000 hadith are the first, Allah SWT alone who created and made love; and secondly, Allah SWT also predicts and determines affection to beings. Then Allah SWT grants a fraction of that love to His creatures (al-'Ayniy, t.th). With this unparalleled gift, man utilizes this love by following all the commandments of Allah SWT and abandoning all his prohibitions (al-Nawawiy, 1392H: 68 \& alMubārakfūriy, 1984). In the meantime, the proof of the creation of sensory objects can be identified with senses such as heaven, earth, hill, sea, river and so on to help the human mind to think of Allah SWT ('Ārîfiy, 1999). This is explained in one other hadith. Rasulullah SAW said:

Which means: From 'Abd Allāh ra, he said: "A pastor came to the Messenger of Allah, saying:" O Muhammad, we have indeed found that Allah has created all the heavens 
above on one finger, creating all the earth's heights on one finger, - Growth on one finger, water and the rest on one finger, and all the creatures on one finger. So Allah Almighty says, "I am the King of kings". So he smiled at SAW so that his molar teeth appeared to agree with the statement from the pastor. Then he read a piece of Allah SWT in the Qur'an that means, "And they do not glorify Allah SWT with the proper pride when the whole earth is in His grasp on the Day of Judgment and the heavens are rolled up with His right hand. Glory to God and Exalted Him above what they associate with Him "(Narrated by al-Bukhari, Hadith No. 4811).

In fact, the hadith 4830 discussed earlier is of a general nature because of the statement of khalaq Allāh al-khalq (Allah SWT has created all beings) encompassing all creatures that are created. In the $\mathbf{4 8 3 0}$ hadith, the Prophet Muhammad SAW has asserted that all creatures and creatures are the creation of Allah SWT. He is the Creator of everything. This general statement is devoted to the details of the creation of the matters set out in hadith no. 4811. These are the seven heavens, seven earthlings, plants, water and all other beings.

The reason for hadith no. 4811 is that at one point, a pastor has come to meet him to ask some questions. The purpose is to seek confirmation of some of the things mentioned in their religious books on the creation of such matters. The question raised by the priest to the Prophet SAW for the sake of certainty about the nature of al-Qudrat Allah Almighty who created it. The Prophet (peace and blessings of Allah be upon him) answered the question by signaling a sign of laughter, thus verifying the truth of the matter raised to him (al-'Asqalāniy, 1376H).

Rasulullah SAW reinforces His reply through a piece of Qur'anic verse that explains the creation of a common nature. Hence, he concludes the discussion by explaining the power of Allah SWT to create everything and it all lies under His power (al-'Ayniy, t.th).

Refers to the discussion of hadith 4830 and 6000 which explains the creation of the rahim (uterus) and affection of Allah SWT. This hadith also functions mentakhșișkan (specialize) the statement of khalaq Allāh al-khalq (Allah SWT has created all creatures) common in hadith 8830 as hadith 4811. This concludes the discussion of hadith 4830, 6000 and 4811 that generally shows Allah SWT creates every creature either in the form of sensory and also moral. The details of the general statement are like the creation of a moral creature of seven heavens and earth, plants, water and so forth, while the instinctive creation of a creature is rahim (uterus), affection and so on. Hence, the discussion of hadith 4830, 6000 and 4811 shows Allah SWT creates all beings with His power. With that, He is also the Owner and is in charge of all His creation. This is explained in the Hadith of Rasulullah SAW:

Which means: From Ibn 'Umar r.a., the Prophet when returning from a war, pilgrimage or umrah, he held a place three times. Then you say: There is no God but Elohim and there is no ally for Him. To Him the Kingdom and to Him praise. He is over everything Almighty. They are the returnees, the repentant, the worshipers, the prostrate and the people who praise Allah SWT. Right in His promise to help His servant and destroy the allies alone (Riwayat al-Bukhāriy, Hadith No. 1797). 
Hadith 1797 shows that only Allah created all things by His will without compulsion from anyone. From the hadith, the word is al-Mulk (For Allah SWT of the kingdom) and the wahuwa 'ala kull syay' Qadir (He is Almighty of all things) shows that Allah SWT has the power to create something according to the predetermined fate (al-Munāwiy, 1988). With this perfect nature, no power can prevent and compete with Allah SWT. All beings belong to Allah SWT and are under His control (IbnKathīr, 1999).

Therefore, man is responsible for gratefulness to Allah SWT, admiring His favor, humility before Him and praising His greatness ${ }^{2}$ (IbnBațțāl, 2003). It is obligatory for man to worship Allah SWT solely on the basis of al-Tawhìd al-Ulūhiyyat (al-Syawkāniy, 2002) and also al-Tawhìd al-Rubūbiyyat (Ibn Bațtāl, 2003). This also refers to human beings as development actors. Given this sacred faith, man should make development as worship to Allah SWT. Not only that, this development actor must admire His favor, humility and always praise His greatness (Salleh, 2003).

Al-Tawhīd al-Ulūhiyyat "This means putting in self-confidence that only Allah SWT alone is entitled to be worshiped and no associate for Him. By adhering to this monotheism, it can distinguish between the holdings of Muslims with the non-Muslim holdings because non-Muslims believe in the existence of god, but did not (AlAțram, 1413H).

As for al-Tawhīd al-Rubūbiyyat, it means Allah SWT who created, possessed and administered this universe. It gives confidence that only Allah SWT creates and empowers all beings. The concept of al-Tawhīd al-Rubübiyyat is more focused on $A f^{\prime} \bar{a} l$ Allāh (acts of Allah SWT) who created and administered the worlds versus al-Tawhïd al-Ulühiyyat which focuses on the One True God Almighty (Zaydān, 2005). This person is also believed by non-Muslims as they also believe that only God is capable of creating and administering the universe perfectly. This is where the difference between these two monotheisms is because only believers who adhere to al-Tawhìd al-Ulühiyyat, while alTawhīd al-Rubūbiyyat are held by Muslims as well as non-Muslims (IbnTaymiyyat, 2005: 1-66; 'AbdAllāh, 1996).

However, there is a dispute between Islamic scholars on the division of the two monotheism. According to al-Kawthariy (2004), real monotheism is not divided into al-Ulūhiyyat and al-Rubübiyyat because both these tauhid are similar. Actually, this division never existed until it was started by Ibn Taymiyyat during his time. Meanwhile, the division on the side of the salaf scholars does not mean anything. According to al-Kawthariy (2004), however, it is irrelevant for a non-Muslim to hold one of the two existing monotheistic al-Rubübiyyat while in the time of the Prophet Muhammad SAW did not divide it in such a way. In the days of Rasulullah SAW, believers are portrayed as having a selfconfidence in self rather than non-Muslims being distinguished by the absence of monotheism on themselves.

Although there is a dispute between the scholars on the division of the faith as stated, the point of equality between the two still exists is the importance of al-'aqĩdat al-șahịhat (true faith) to the Muslims (Al-Asyqar, 1991: 22-23).

This true concept of faith is the heart of man on this earth. It is a driving force for a harmonious and prosperous human life. This concept is not limited to the divine aspect, but it goes beyond all

\footnotetext{
2 With all the blessings and blessings that Allah has bestowed on it, it is also necessary for a servant to be confident in his presence and to adhere to the teachings of al-Tawhịd al-Ulūhiyyat and his al-Rubübiyyat (Mohd Shukri Hanapi, 2012: 292).
} 
aspects, especially human life (Nurhakim, 2008: 27). With the concept of al-'aqĩdat al-șahịhat this is, man can live life by following all the rules and laws especially in the matters of the Shari'a. With this law, man can achieve all success in the world and the hereafter (Zaydān, 2005: 16-22; Kamsah et al., 2004: 77).

Similarly in the aspect of development, this true concept of faith is the essence of human development on earth. Based on this concept, development actors can regulate development activities in accordance with Islamic rules. With this, humans will achieve the pleasure of Allah SWT through the development (Salleh, 2003).

In addition, al-Zindāniy (2003) states that there are three implications of the concept of al'aqìdat al-șahihat if applied to human life. First, people will know the truth. The truth that is meant is that man knows his purpose is created, the beginning and the end of his life. This truth will guide man on a straight path and far from error; second, the maintenance of human relationships with humans. This concept brings people together with the nature of brotherhood and the feeling of love and affection that exists in themselves. They will automatically help in goodness and prevent from doing evil; and thirdly, human ability. Humans are created in a state of weakness. That is why people need the help of Allah SWT in all things. With this little human effort, Allah SWT also opens the widest gates of kindness on His side.

\section{CONCLUSION}

In view of this, it can be seen how important the application of al-'aqĩdat al-ṣahịhat in human life is certainly in administering this earth. If al-'aqĩdat al-șahịhat plays an important role in human life, then it is also very important in the development of human being on this earth in general and its particular integrity and accountability. In the context of the development of integrity and accountability, the concept of al-'aqīdat al-șahịhat is very important. Based on the description of these hadiths, the people who carry on the development of this earth need a spur which will have a positive impact on their efforts. The spine must be based on the existence of Allah SWT and His presence. It is because, He is the creator of nature, all beings, the heavens and the earth and the contents of both man and nature. Not just physical creation, even Allah SWT creates something abstract like feeling, desire, heart, spiritual and so forth. It is therefore an obligation to man to stick to the concept of al-'aqìdat al-șahịhat in all matters including in carrying out integrity and accountability development activities. Based on this concept, humans can manage better development in their lives.

\section{Acknowledgement}

This paper is founded on the research project of the Fundamental Research Grant Scheme FRGS/1/2018/SSI03/UNISZA/02/2. Special appreciation is owed to Ministry of Higher Education Malaysia (MOHE) and Universiti Sultan Zainal Abidin (UniSZA) for sponsoring and supporting this research. 
INTERNATIONAL JOURNAL OF ACADEMIC RESEARCH IN BUSINESS AND SOCIAL SCIENCES

Vol. 8, No. 11, Nov, 2018, E-ISSN: 2222-6990 @ 2018 HRMARS

\section{Corresponding Author}

Wan Khairul Aiman Wan Mokhtar (Ph.D), Senior Lecturer, Faculty of General Studies and Advance Education (FUPL), Universiti Sultan Zainal Abidin (UniSZA), Kampus Gong Badak, 21300 Kuala Nerus.

E-mail:wk_aiman@yahoo.com / wkhairulaiman@unisza.edu.my

\section{References}

Zaydān, A.A.K. (1993). Al-mufașșal fĩ aḥkām al-mar'aț wa al-bayt al-Muslim fí al-syarīat alIslāmiyyat. Beirut, Lubnan: Mu'assaț al-Risālaț.

'Ārifiy, S.A.AM. (1998). Al-adillaț al-'aqliyyaț al-naqliyyaț 'alā ușūl al-i'tiqād. Mekah: Dār 'Ālam alFawā'id.

Al-Asqalāniy. (1998M/1424H). Fatḥ al-Bārī. 'Abd al-'Azīz Bāz (Ed.). al-Qāhiraț, Mesir: Dār al-Ḥadīth. Al-'Ayniy. (n.d). 'Umdaț al-qāriy syarḥ Șaḥị̣ al-Bukhāriy. Beirut, Lubnan: Dār Ihyā' al-Turāth al'Arabiy.

Al-Asyqar.(1991). Al-Tawhīd miḥwar al-ḥayāt. Amman: Dār al-Nafā'is.

Al-Ațram. (1413H). Al-as'ilaț wa al-'ajwibat fi al-'aqīdaț. Al-Riyāḍ: Dār al-Wațan.

Al-Bājūriy. (2010). Syarḥ al-imām al-Bājūriy 'alā jawharaț al-tawhīd. Musțafā Dib al-Bughā (Ed.). Damsyīq: Dār al-Mustafa.

Al-Balīhiy. (1404H). 'Aqidaț al-Muslimīn wa al-radd 'alā al-mulḥidīn wa al-mubtadi'in. Al-Riyāọ: alMațabi' al-Ahliyyat li al-Ufsut.

Al-Bukhāriy. (1980). Șaḥị̣ al-Bukhāriy. Al-Qāhiraț, Mesir: al-Mațba'aț al-Salafiyyaț.

Al-Fathani. (2010). Mutiara ilmu aqidah. (Abdul Ghani Jabal Maraqy, Terj.). Kota Bharu: Jabal Maraqy Enterprise.

Al-Kawthariy. (2004). Al-'aqīdaț wa 'ilm al-kalām min a'māl al-imām Muḥammad Zāhid alKawthariy. Beirut, Lubnan: Dār al-Kutub al-'Ilmiyyaț.

Al-Khalwatiy. (n.d). Tafsir rūḥ al-bayān. Al-Qāhiraț, Mesir: Dār Ihyā' al-Turāth al-'Arabiy.

Al-Munāwiy. (1988). Al-Taysīr bi syarḥ al-Jāmi' al-Șaghīr. Al-Riyāọ: Maktabaț al-Imām al-Syāfi'iy.

Al-Nawawiy. (1392H). Syarḥ al-nawawiy 'alā Șahịḥ Muslim. Beirut, Lubnan: Dār lhyā' al-Turāth al'Arabiy.

Al-Sa‘adiy. (2000). Taysīr al-Karīm al-Raḥmān fí tafsīr kalām al-Mannān. Beirut, Lubnan: Mu'assasaț al-Risālaț.

Al-Suyūțiy. (1988). Asbāb wurūd al-ḥadīth, aw al-luma' fĩ asbāb al-ḥadīth. al-Manșūraț: Dar alWafā'.

Al-Syahrastaniy. (1992). Al-milal wa al-niḥal. Aḥmad Fahmiy Muḥammad (Ed.). Beirut, Lubnan: Dār al-Kutub al-'Ilmiyyat..

Al-Syawkāniy. (2002). Nayl al-awțār min muntaqā al-akhbār. Beirut, Lubnan: Dār al-Madār alIslāmmiy li al-Tawzī'.

Al-Ṭanțāwiy. (1992). Al-tafsīr al-wasīṭ li al-Qur'ān al-Karīm. Beirut, Lubnan: Dār al-Ma'ārif.

Al-Zindāniy. (2003). Kitāb al-tawhīd. Beirut, Lubnan: Mu'assaț al-Risālaț.

IbnBațțāl.(2003). Syarḥ Șaḥị̣ al-Bukhāriy. Al-Riyāọ: Maktabaț al-Imām al-Syāfi'iy Rusyd.

IbnKathīr. (1999). Tafsīr al-Qur'ān al-'Ażìm. Al-Riyāọ: Dār Tayyibaț li al-Nasyr wa al-Tawzī'.

IbnTaymiyyat. (1991). Majmū'al-fatāwā (Jld. 1-13). Riyad: Dār al-'Ālam al-Kutub.

'AbdAllāh. (1996). Al-tadarruj fi da'wat al-nabiyy. t.tp: Wizāraț al-Syu'ūn al-Islāmiyyaț. 
Nurhakim, M. (2008). Jatuhnya sebuah tamadun. Batu Caves: PTS Islamika.

Kamsah, M.F., Razak, A.Z.A. \& Zakaria, N.S. (2004). Merancang kejayaan. PTS Milenia- siri pembangunan diri). Kuala Lumpur: PTS Litera Utama.

Salleh, M.S. (2003). 7 Prinsip pembangunan berteraskan Islam. Kuala Lumpur: Zebra Editions Sdn. Bhd. dan Pulau Pinang: Projek Pengurusan Pembangunan Islam, Pusat Pengajian Sains Kemasyarakatan, Universiti Sains Malaysia.

Marican,S. (2005). Kaedah penyelidikan sains sosial. Petaling Jaya: Pearson Malaysia Sdn. Bhd. Al-Qựāt, Syaraf. Personal Communication, December 17, 2014. 